\title{
Understanding Social Entrepreneurship and Features of It
}

\begin{abstract}
Fatih Öztürk*
Social entrepreneurship has become a significant field of academic literature for about twenty years. A growing attention to social entrepreneurship has appeared since then. Scholarly interest for it stems from its mission in society that brings affective solutions to the existing social issues, presents distinctive perspectives to the individuals and creates a social value. The purpose of this paper is to provide a view of social entrepreneurship as a process that contributes to social wealth, explores the opportunities for social change and leads to social ventures. Social entrepreneurs have addressed essential human needs that have been ignored and forgotten by the current institutions and businesses. Therefore, this review also assesses the characterizations in social entrepreneurial and conventional entrepreneurial dimensions. It highlights major differences and similarities between these two forms of entrepreneurship with their backgrounds. The content of social entrepreneurship and examples of current successful social ventures conclude this work.
\end{abstract}

Keywords: social entrepreneurship, profit, value creating, initiative.

Submitted: 6.10.2013 | Accepted: 4.12.2013

\section{Przedsiębiorczość spoleczna - pojęcie i funkcje}

Na przestrzeni ostatnich dwudziestu lat zainteresowanie tematyka przedsiębiorczości spotecznej znaczaco wzrosto. Naukowe zainteresowanie ta stosunkowo nowa dyscyplina wynika przede wszystkim z roli, jaka odgrywa w spoteczeństwie. Zwraca uwagę na bezpośrednie oddziatywanie przedsięwzięć na ludzi, prezentując specyficzny punkt widzenia $w$ rozwiązywaniu problemów spotecznych. Celem niniejszej pracy jest dostarczenie wiedzy na temat przedsiębiorczości społecznej jako procesu, który przyczynia się do wzrostu zamożności społeczeństwa, bada możliwości, jakie moga z niego wyniknać i ukazuje do jakich przedsięwzięć prowadzi. Dziedzina przedsiębiorczości spotecznej wypetnita lukę, która dotąd nie pozostawała w kwestii zainteresowań innych instytucji i przedsiębiorstw, zajmując się dotychczas ignorowanymi $i$ zapomnianymi problemami. Zatem, $w$ pracy tej zestawione zostaty charakterystyczne elementy dla przedsiębiorczości społecznej wraz z jej konwencjonalnym rozumieniem oraz przyktady wielu skutecznych przedsięwzięć społecznych.

Słowa kluczowe: przedsiębiorczość społeczna, zysk, kreowanie wartości, inicjatywa.

Nadesłany: 6.10.2013 | Zaakceptowany do druku: 4.12.2013

JEL: M13, A13

\footnotetext{
Mgr Fatih Öztürk - Studia doktoranckie, Wydział Zarządzania UW.

Adres do korespondencji: ul. Obrońców Tobruku 19/27, 01-494 Warszawa; e-mail: fatihozturk037@ gmail.com.
} 


\section{Introduction}

Social entrepreneurship is a term that refers to the growing number of scholars, researchers and organizations that have interested in it. It has become an academic field that yields significant findings to individuals who embark to assess its bases and scopes. In spite of the growing attention to social entrepreneurship, there are still points which require clarification and development. Social entrepreneurship is based on different concepts compared to other entrepreneurship forms. Value creating and social benefit are the subjects of their interest that the existing institutions and enterprises failed in creating. Hence, social entrepreneurial actions become the effective voice of the individuals who point out that current forms of services are not on the desired level that can answer to the needs of communities. Success of social entrepreneurship encouraged those people whose discontent made them react.

In this research, above brief aspects of social entrepreneurship are considered in detail. Features of social entrepreneurship and its literary foundation are analyzed. However, this work contributes in highlighting the various literature interpretations, determining the field of concept, and presenting the impact comparison of social entrepreneurship. Emphasizing on the implemented fields of social entrepreneurship will occur towards the end and it will provide explicit perspectives to come up with comparison possibility.

\section{Definition}

The definition of social entrepreneurship and illustrating its conceptual boundaries are not seen as an easy task (Cho, 2006). An important fact of that difficulty is that people who are in different geographical and cultural contexts have distinctive behaviors, life styles and traditions. Social entrepreneurial activities appear in these various places that complicate to present a clear definition. Along with such contextual diversity, the language of social entrepreneurship is new (Dees, 1998) and definitions that are made different. Therefore, there is no commonly acknowledged definition of social entrepreneurship in spite of the fact that it is studied as a model whose goal is to remove social disequilib- rium and create a more ideal state (Light, 2008). However, this phenomenon involves an underlying definition as the essence and initial phase of this paper. In this regard, social entrepreneurship is based on the innovative and social value creating activities and these activities are the common fields for the nonprofit, business and public sector (Austin, Stevenson \& Wei-Skillern, 2006). Another definition stressed by Fowler (2000) is that social entrepreneurship is the progress of value creating that feasible (socio-) economic structures, individuals, governmental and nongovernmental organizations get involved and each of these actors and practices are basically for social profit. Peredo and McLean (2006, p. 56) also enumerated the definition features of social entrepreneurship as follows:

"[S]ocial entrepreneurship is exercised where some person or persons (1) aim either exclusively or in some prominent way to create social value of some kind, and pursue that goal through some combination of (2) recognizing and exploiting opportunities to create this value, (3) employing innovation, (4) tolerating risk and (5) declining to accept limitations in available resources."

Many of literarily definitions of social entrepreneurship have taken part in the past academic researches. According to chronological progress of the phenomenon, it can be claimed that social entrepreneurship will be the ground for the many academicians and researchers further in the future. In addition to this, Table 1 presents the statements and definitions regarding social entrepreneurship which have been found in literature and defined by different authors. This presenting is not only an attempt for summing up the diverse dimensions of definition. On the contrary, it is an essential point that will contribute to comprehend the entire phenomenon.

As can be seen in Table 1, the various definitions of social entrepreneurship were defined and the core sense of the term has been emphasized as social mission. Furthermore, almost each statement gives priority to the term of value creating for the good of society. In this sense, the meaning of social entrepreneurship may differ for the different group of people. Due to the fact that values state different things for the people, important goals in their life, sense of cherishes and meaningful actions determine value reflection (Davis, 2002). Hence, 
Table 1. Definition of Social Entrepreneurship

\begin{tabular}{|l|l|}
\hline \multicolumn{1}{|c|}{ Author / Year } & \multicolumn{1}{c|}{ Definition } \\
\hline $\begin{array}{l}\text { Mort, Weerawardena } \\
\text { and Carnegie (2002) }\end{array}$ & $\begin{array}{l}\text { Social entrepreneurship is a multidimensional construct involving the } \\
\text { expression of entrepreneurially virtuous behavior to achieve the social } \\
\text { mission, a coherent unity of purpose and action in the face of moral } \\
\text { complexity, the ability to recognize social value-creating opportunities } \\
\text { and key decision-making characteristics of innovativeness, proactiveness } \\
\text { and risk taking. }\end{array}$ \\
\hline $\begin{array}{l}\text { Mair, Robinson and } \\
\text { Hockerts (2006) }\end{array}$ & $\begin{array}{l}\text { The concept of social entrepreneurship is, in practice, recognized as } \\
\text { encompassing a wide range of activities; Enterprising individuals devoted } \\
\text { to making a difference; social purpose business ventures dedicated to } \\
\text { adding for-profit motivations to the nonprofit sector; new types of } \\
\text { philanthropists supporting venture capital-like "investment" portfolios; } \\
\text { and nonprofit organizations that are reinventing themselves by drawing } \\
\text { on lessons learned from the business world. }\end{array}$ \\
\hline Robinson (2006) & $\begin{array}{l}\text { “.. I define social entrepreneurship as a process that includes: the } \\
\text { identification of a specific social problem and a specific solution... to } \\
\text { address it; the evaluation of the social impact, the business model and } \\
\text { the sustainability of the venture; and the creation of a social mission- } \\
\text { oriented for-profit or a business-oriented nonprofit entity that pursues } \\
\text { the double (or triple) bottom line." }\end{array}$ \\
\hline $\begin{array}{l}\text { Martin and Osberg } \\
\text { (2007) }\end{array}$ & $\begin{array}{l}\text { Social entrepreneurship is the: 1) identification a stable yet unjust } \\
\text { equilibrium which the excludes, marginalizes or causes suffering } \\
\text { to a group which lacks the means to transform the equilibrium; } \\
\text { 2) identification of an opportunity and developing a new social value } \\
\text { proposition to challenge the equilibrium, and 3) forging a new, stable } \\
\text { equilibrium to alleviate the suffering of the targeted group through } \\
\text { imitation and creation of a stable ecosystem around the new equilibrium } \\
\text { to ensure a better future for the group and society. }\end{array}$ \\
\hline
\end{tabular}

Source: own study.

social entrepreneurship (as well as it is a global phenomenon), in some sort, may be described as a specific study of field that comprises diverse habits, different cultural perspectives or social attitudes.

\section{Social Entrepreneurial Dimension}

The publications, studies and ongoing scholarships relevant to the social entrepreneurial dimension are not on the desired level. It is a fact that a gap exists which requires scholarly explorations. Fulfillment this gap would be an inspiration for social entrepreneurs, field for institutions, academics and legislators (Skoll, 2006). Therefore, many distinctive studies and research projects have been issued for examining the motivation, background and process of social entrepreneurship. After this point, social entrepreneurs are defined as notfor-profit executives whose interests do not stay at a distance from market relations. Their mission is to balance ethical values that gain meaning as a driving force for their actions (Boschee, 1998). The most explicit feature of social entrepreneurs is determined by social perspective of their venture. Certo and Milner (2008) asserted that societies and members of them may be in need of services that are significant for their existence such as providing food, water, shelter, medical services or education. Responding those needs points the social value creating more than aiming the financial profit. Therefore, social entrepreneurs may ask questions such as: What are the reasons for poverty? How to prevent air pollution? Why the policies for saving clear water sources are not enough? What kind of regulations have to be implemented in order to protect children from the child labor? Innovative solutions are implemented after such questions because of the fact that social entrepreneurs have 
ability to give place to innovative solutions in their actions. In this respect, their characteristics enunciate to create a social value by applying innovative ideas (Santos, 2009).

Social impact and value creating expressions have remained limited under the tradition of charity, donation or gifting since many years. But after rising of the social entrepreneurship phenomenon, comprehension and outlook to the social value creating notion have changed. Moreover, social entrepreneurs have become the initial actors of the mentioned transition. Center for the Advancement of Social Entrepreneurship (CASE) (2008) reported that social entrepreneurs carry out their ventures in the structure which relies on accustomed, traditional nonprofit progresses rather than comprehensive investments which create social impact. Although the conditions where the terms of charity have been adopted, social entrepreneurs try to remedy for completion of their actions. Hence, they apply various organizational forms in order to transform their ventures from charity context to notfor-profit commercial initiatives. So that, it advances to social level and increases the social outcome (Nicholls, 2006).

Summing up, social entrepreneurs are the people whose new ideas centralize the appearing social problems, who will force each opportunity in order to sustain their vision and who simply will not give up unless they will obtain their framed goals (Bornstein, 2004). In addition to the conclusion in this part, Dees (1998, p. 4) defined the baselines of social entrepreneurial dimension as follows:

- Social entrepreneurs play the role of change agents in the social sector, by:

- Adopting a mission to create and sustain social value (not just private value),

- Recognizing and relentlessly pursuing new opportunities to serve that mission,

- Engaging in a process of continuous innovations, adaptation, and learning,

- Acting boldly without being limited by resources currently in hand.

\section{Characteristics of Social Entrepreneurs}

Conducted studies and researchers have emphasized the social entrepreneurial nature by expressing their particular behaviors and characteristics. Researchers
Hoogendoorn, Pennings and Thurik (2010) gather the empirical findings along five themes which are subject to the individual perspective. These are skills, background / experience, discourse, demographics and motives. Nevertheless, one fact should not be skipped is that mentioned clustered themes are not a widely agreed form of characteristics of social entrepreneurs. Social entrepreneurial behaviors may be issued with various aspects according to depth of investigations. For example, Mair and Noboa (2006) reported only three titles of characteristics in their research. They are stated as follows: traits and skills, behavior, context and background. But in this paper, the first format of characteristics is presented due to the reason that it covers more comprehensive point of view for the academic researchers.

\section{Skills}

Business entrepreneurs are driven by profit approach that is the essential for their existence. Compared to this, social entrepreneurs are motivated by socially targeted goals which distinguish their characteristics from business entrepreneurs. Provided traditional governmental services such as welfare, housing and health care are considered and developed by an innovative way which is cheaper and more efficient. It is an important point that makes social entrepreneurial ventures distinctive and presents their great skill (Leadbeater, 1997). However, Dees (1998) claimed that individuals may be seeking different types of pioneers for their society. Social entrepreneurs' specific characteristics reveal that they have the ability to overcome social issues with their leadership skills. To conclude, social entrepreneurs are identified as the leading power of their society and their great challenge is that they utilize innovative way of thinking for social development.

\section{Background / Experiences}

"I was struck by the similarity in their stories: The social entrepreneurs had all spent years gaining skills and experience in different environments before they were exposed to a problem that seized them often something painful." These were the thoughts of Bornstein (2005, p. 13) that he expressed when he explored the inner 
worlds and backgrounds of the social entrepreneurs. However, characteristics of social entrepreneurs is commonly identified with both activists and entrepreneurs. Their family background and past working experiences construct their future initiatives. As a matter of fact that mentioned experiences bring out the source of their motivation. It may be inferred from Bornstein's statement that experience factor has high importance of the created characteristics of social entrepreneurs - as much as the innate skills have-. Nevertheless, the background of social entrepreneurial activity mostly encompasses the experience of social entrepreneur. Hence, as found in many scientific papers, background and experience terms have the complementary qualities for each other. In addition to this, Perrini and Vurro (2006) contributed to this factor as follows:

Personal experience: It is expressed to personal experience that has impact on the social ventures which were developed by social entrepreneurs. For example, living abroad, joining in a distinct society or enhancement of approaches to the social matters.

Previous experience: This phrase refers to experiences that lived in the past and shaped the social entrepreneurs' activities. Significance of previous experience is that it gives idea to understand social background of social entrepreneurs' personalities. Previous experiences may be named as a path that social entrepreneurs come up with their ideas to the current time. In this respect, it integrates the existing reality and social gaps along with innovative ideas for social impact. Moreover, behind the social entrepreneurial activities former relations stand and those experiences indicate to important models who had influence on social entrepreneurs' decisions in their past life. As a result, current social-mission ventures that social entrepreneurs set are actually based on their previously lived experiences that create one of the most significant motives of their characteristics.

\section{Discourse}

Social entrepreneurs pay attention to collective-need driven actions and bring positive contributions to society rather than gaining profit out of their actions (Hoogendoorn et al., 2010). Their purpose is often far from the obtaining financial success. In spite of the fact that they follow up some of the conventional entrepreneurial behaviors in their ventures, in fact both are driven by distinctive logic. The explicit point of the discourse (at individual and organization level) is this collective logic. Business and entrepreneurship are the concepts which are the contributory factors for a social enterprise (Hoogendoorn et al., 2010).

\section{Demographics}

According to findings out of the works that were overviewed, most of the studies concerning social entrepreneurship have lacked in examining the demographic of individuals such as age, gender or education. This term argues the impact of the some of mentioned criterions on the social entrepreneur's personality. For instance, entrepreneurial activities below a particular age or individual contribution of higher education on the social ventures.

\section{Motives}

The motives for business entrepreneurs are uttered such as independency of actions, determination to obtain profit or self confidence. Compared to business entrepreneurship, social entrepreneurs' motives are for the social benefit. The factors that they are inspired hinge upon the existing issues. For instance, fulfillment of the social gaps that are essential, benevolence of the individuals surrounding them or responsibility feeling.

\section{Economical Background}

Since the cold war ended, the balance of power in the world has changed and it has been reconstructed among the new world's countries on martial, political, social etc. bases. Because of that reshaping of such essential notions, economical criterions have been influenced as well. Free market and capitalist ideologies have swept the globe and many of free enterprises have prospered after the new world order. However, despite of the economical growth and wealth gained, the new economical system has brought ethical and moral issues along. $\mathrm{He}$ (2008), Chinese economist, argued that 
moralizing the market is relevant to global market expansion and its consequences. Discussions about it highlights the importance of economic actors whose priorities do not strictly embrace the socio cultural matters. In this sense, mentioned economic actors who are states, international organizations, civilian groups and movements must consider moral concerns more than aiming to structure dynamics of the market. Afterwards more desirable behaviors may be obtained. New economical policies indisputably created their own wealth but the fact is that they have failed many of people as well. Besides it, there are some significant tools that are used for measurement of the market. These measures are simple and unambiguous that address to market share, scale and profit (Murray, Grice \& Mulgan, 2010). Yunus (2007) described the markets that are not fettered do not analyze the solutions for social problems. Instead of focusing on the social context, their current forms bring along issues which are poverty, pollution, corruption, disease or inequality.

When technological developments were accelerated, social welfare and economical indications increased, the distance between individuals who belonged to different levels of income in society grew at the same time. This problematic case eventually created the point "the greatest challenge of the twenty first century is the growing gap between the rich people on earth and the poor people on earth" (Carter, 2009, p. 13). Due to the reason that this vital gap has occurred, social entrepreneurship has risen as a global phenomenon. Thereafter, it has brought a new perspective to society in order to reveal that social matters can be also overcome by ventures which are different from governmental or direct commercial initiatives. Moreover, it has been experienced that social entrepreneurship has made a visible impact on the extension of economy and solutions that society has. Hence, social entrepreneurship has been acknowledged and its economical aspect has been a field of study that many of policy makers, researchers and business schools have considered.

\section{Historical Background}

When the social entrepreneurship phenomenon is introduced and presented, his- torical background and past examples of it must be highlighted as well. Hence, in this part of paper, a brief summary of historical perspective of phenomenon will be presented. Nicholls (2006) explained that the term of "social entrepreneurship" was found by banks in 1972 after the realization of social issues which were overcome by managerial practices. Before that, many historical names have taken significant roles to prevent social problems and these names can be defined as the inspiring models for today's social entrepreneurs. For example, Florance Nightingale, whose theory revolutionized the health care and changed conditions of hospitals in the late of 1900s (Bornstein, 2004), Dr. Maria Montesorri, who was founder of Casa dei Bambini (Children's Home) in the beginning of 1900 s, discovered the importance of concentration and investigation of young children. After that, examined children became ordered, they developed self-control and their feelings became more peaceful (Seldin \& Epstein, 2003) and Mahatma Gandhi, who was the most significant political and spiritual pioneer of India, believed that the used ways and methods for achieving to overcome small problems in society could be also applied for fixing the greatest problem of his country (Datta, 1961). Above three exceptional historical figures are just the evidence that communities, cultures, whether eastern or western, may be in need of persons who are willing to pay attention to the occurred social matters. They are the individuals who have the social visions and tend for value creating. It can be stated that these features are also descriptive for the modern social entrepreneurs and missions of them inside of society.

\section{Which is Socially Responsible: The Business or The Individual?}

Since social entrepreneurship played a significant role in bringing innovative solutions for the existing problems of society, responsibility dimension of it was started to question. How to name an organization with social purpose? Who can be called responsible? What do individuals tend to obtain inside of the organizations? It is clear that generating such question marks are possible. Friedman (1970, p. 1) gave a remarkable response to the ques- 
tions which are asked toward the sense of responsibility:

"The discussion of the "social responsibilities of business" are notable for their analytical looseness and lack of rigor. What does it mean to say that "business" has responsibilities? Only people have responsibilities. A corporation is an artificial person and in this sense may have artificial responsibilities, but "business" as a whole cannot be said to have responsibilities, even in this vague sense. The first step toward clarity in examining the doctrine of the social responsibility of business is to as precisely what implies for whom."

The purpose of social entrepreneurial actions should be emphasized to explore the source of mentioned responsibility term. Much researches and studies were conducted in relation to social entrepreneurs' purposes and approaches. Hoogendoorn et al., (2010) reported that social entrepreneurs are defined by innovative school of thought as individuals whose innovative ideas guide their actions. They are volunteers who meet social problems and tackle them with their approaches. Their creative ideas which address needs of society focus on system change, they have the ability to manage appeared risks and they have high tolerance for ambiguity (Dees, 1998). Their characteristics and features of motivation differ from commercial entrepreneurship. For example, they are individuals who are open to social criticism, they have endurance in case of failing therefore they are without apprehensive feelings. They have ability to develop the empathy, they have mostly good communication skills and they can bring creative responses for customer needs. It is clearly understood that social entrepreneurs must have additional motivation methods to accomplish difficulties that they may encounter on their path. Summing up, according to arguments that were found, the socially responsible in a social organization are executives, employees, volunteers and the other individuals who actively contribute to run enterprise with their entrepreneurial skills. The business point of it is just a method of way, which is essential, to find solutions for social issues.

\section{The Entrepreneurial Aspect}

Entrepreneurial activities are the foundations of emerging social entrepreneurship phenomenon. Compared to traditional social initiatives, social entrepreneurship ventures may apply to conventional entrepreneurship methods. French economist Jean-Baptiste Say, in the early nineteenth century, defined entrepreneur as person who "shifts economic resources out of an area of lower and into an area of higher productivity and greater yield". However, French literal translation of entrepreneur is "one who undertakes" to create value (as quoted in Dees, 1998, p. 1). In theory, entrepreneurship is the process that new firms attempt to apply when entering in the market. Entrepreneurial initiatives lead the market processes, develop the economy and provide options to the customers. Entrepreneurs exploit from each opportunity to create new businesses and as a motive of their characteristics, they enjoy while they are doing it (Dees, Emerson \& Economy, 2001). In addition to this, entrepreneurial opportunities can be described as the crucial force of their actions such as innovative goods, services or market gaps. Those opportunities are integrated with creative ideas of entrepreneurs that are the formation of new means and relationships (Shane, Locke \& Collin, 2003). In a nutshell, Entrepreneurial ventures in a market certainly contribute to economy and growth of a country. Their innovative way of thinking and courage for embarking in fuzzy spaces in the market create their difference compared to regular individuals. As an outcome of their actions, they churn and displace the economical values in positive way (Davidsson, 2008).

\section{Difference Between Social Entrepreneurs and Conventional Entrepreneurs}

Many outcomes may be obtained by successful conventional enterprises in the market and it is the fact that opportunities that appear in front of the entrepreneurs are the central point of their actions (Drucker, 1985). Although the primary goal of an conventional enterprise which is well organized and structured is to reach a financially targeted profit line, entrepreneurs may aim for various goals for their business achieve- 
ment. These goals may include distinctive dimensions as personal, financial or social. Since here is the phenomenal substratum that business entrepreneurship has not accomplished to fulfill the social needs in the strict sense, social entrepreneurship has come up. However, social entrepreneurship resembles business entrepreneurship in some sorts. But in fact it differs with its purpose of running. The basic differentiation among the social entrepreneurs and conventional entrepreneurs is that the idea of creating a better world represents the core of social entrepreneurial thought (Dees et al., 2001). Another interpretation of this subject and perhaps the most important one is that social entrepreneurs embark to alleviate common and apparent social problems which are mostly overlooked by conventional entrepreneurs. In addition to this, Mair and Noboa (2006, p. 121) juxtaposed the major points:

- Social entrepreneurs are moved by different motivations to discover and exploit a distinct category of opportunities.

- The way they pursue opportunities might diverge from typical business approach.

- The outcome social entrepreneurs aim for involves both social and economic aspect.

Concluding, social entrepreneurs are the individuals who stride for the good of community in which they are. The issues and problems surrounding them are actually the basis of their actions. Compared to social entrepreneurs, conventional entrepreneurs are mostly driven by various factors such as financial profit, creating new business ideas or expanding their businesses. Nevertheless, commercial initiatives are the foundations for the growth of the economy of a country. Hence, they have positive impacts on the economy. After this point, another significant difference between conventional entrepreneurs and social entrepreneurs may be expressed. Conventional entrepreneurs consider their personality during their actions and afterwards they attempt to find out new ways and profitable methods for gaining achievement. But social entrepreneurs are motivated by the social success. Therefore, they first attempt to create appropriate value without considering their own personality (Santos, 2009).

\section{The Impact of Social Entrepreneurship}

Financial and social conditions of countries have evolved since modern age's tools and technological transitions have emerged. Economies and borders have been interpreted from a disparate perspective that has not been looked at before. But the issues occurring in societies and the need of human beings do not differ much from the past examples. In this context, whether governmental or non-governmental social organizations, they are established to resolve existing problems. Social entrepreneurship is one of those models that contributes to economy for overcoming of occurring issues by its major goals which are social, economic and community development (Reis, 1999). To achieve these goals, social entrepreneurs who aim to produce solutions which are sustainable, financially, organizationally, socially and environmentally (Thake \& Zadek, 1997) take initiative with their ventures. So that, their ventures influence social outcome and social change. In addition to this, Perrini and Vurro (2006, p. 76) listed the fields in which social transformation is expected to be reached:

- Arts, culture and humanities

- Children and youth

- Community and economic development

- Disaster relief

- Education and research

- Employment training

- Environment and sustainable development

- Health enhancement

- Homelessness

- Hunger and poverty relief

- Rehabilitative service

All these above fields are the indicators of social entrepreneurship's significant impact on the progress of social outcome. Furthermore, according to level of countries, development models, methods and targets of the social ventures differ. As will be illustrated in the cases part of this paper, social entrepreneurs focus on subjects to which they apply their entrepreneurial characteristics. For instance, the Grameen Bank case may be the global picture in the case of unfurling effectiveness of social initiatives. The innovative idea of landing micro-credits to the poor people of Bangladesh was the foundation of the Grameen 
Bank venture. In spite of the large number of local people that benefited, growth of impact did not stop. On the contrary, it expanded more and became the pioneer for the development of micro-finance sector and created nearly 30 businesses which are structured to remove poverty (Yunus, Moingeon \& Ortega, 2010). In a nutshell, social entrepreneurship is entitled as a model which societies apply it as a pioneer power of social outcome and transformation. In addition to all the factors that are stated, social entrepreneurship creates its own range of interest which means the individuals who are inspired and encouraged to address issues of their society.

\section{Boundaries of Social Entrepreneurship}

Emerging research fields and contexts do not include clear bases. Their theoretical boundaries mostly have lack of knowledge that is stated as a common feature for the emerging phenomenons (Marti, 2006). Hence, the context and boundaries of social entrepreneurship remain vague compared to other disciplines and research fields. Martin and Osberg (2007) mention two primary forms of socially valuable activities. They believe that these forms are needed to be distinguished from social entrepreneurship. Also, these two forms actually indicate that the boundaries of social entrepreneurship differ from other forms of social ventures. The first type of social venture is social service provision. The committed and charitable individuals are the central point of such activities. For example, women who are abused by their husbands and who are wounded. As a venture, a woman shelter may be built in order to protect such vulnerable women from their husbands. This definitely creates a difference and prevents much of the violence toward women. But the scale of it likely remains weak because of the fact that there are millions of women who struggle with mentioned problem. Moreover, replication of such ventures becomes difficult and thus, it does not refer a leading venture which has huge impact. The basic difference between social services and social enterprises is not on individuals' characteristics level. Rather it differs in its results and scale. The second type of social venture is social activism. Santos
(2009) defines this phrase as the groups of citizens that are not satisfied with governmental services and they show these externalities by their activist movements. They have also similar motivation sources as social entrepreneurs have. They are social mission oriented, committed, idealist and their activities are inspiring. But instead of direct actions, they attempt to give indirect reactions for the problems such as, social equilibrium, health care, poverty or pollution (e.g., Green Peace or informal social movements). They pressure the governments or protest against the incorrect regulations in the existing system. But they emphasize on activism for social problems rather than direct initiatives. It creates their distinct point which is different than social entrepreneurs.

In a nutshell, all of these ventures combine similar features on the individual point. Their characteristics and attempts draw a common picture as social value creating. Their motivation does not relay on external units, rather they are leading persons who are willing to contribute positively to the community or country in which they are. But social entrepreneurship as a recent phenomenon differs with its progress, scale of impact and innovative way of thinking. Social ventures and social activists are distinctively based on traditional foundations of the social change thought.

\section{Social Entrepreneurship Cases}

The number of initiatives of the social entrepreneurship over the globe have grown in recent years. It has provided new perspective to the responsible individuals. Furthermore, social entrepreneurship's features which make it different from other social ventures brought about an interest to it. In this respect, below cases will emphasize a few of social entrepreneurship ventures in order to provide a wider perspective to field of study.

\subsection{Case of Grameen Bank (Bangladesh)}

Muhammad Yunus is an economics professor who was awarded with Nobel Peace Prize in 2006 (Yunus et al., 2010). But the world has heart about him much before than he had Nobel Prize. He became a well known social entrepreneur with the success of the Grameen Bank which was 
founded by him. After his academic career abroad he came back to his mother country Bangladesh and originated the model of the Grameen Bank in 1976 (Nicholls, 2006). The Grameen Bank created a new model that large-scale of "microlending" credits were used by the poor people. It created an impact to reduce poverty so that it became an institution which was internationally respected (Brock \& Ashoka, 2008). The ways of implementations and purpose of the Grameen Bank became a model for the other institutions as well. To clarify the structure of the Grameen Bank, the implemented microlending system differs from other bank loans with three aspects: First, the essential structure has to be protected in order to be successfully re-paid. Hence, system designing has priority in the structure. Second, there are many people who are interested in and who desire to exploit from the Grameen Bank. Due to the fact that the country has high percentage of poverty and people constantly request for lending, only the landless people and the poorest villagers have right to receive loans. Third, the bank sets a primary goal that women who are socially and economically vulnerable receive loans (Seelos \& Mair, 2005). As a regional result of the microlending system, the Grameen Bank provides loans over 7.5 million people and the importance of it is that 97 percent of people who receive loans are women. Another achievement of the Grameen Bank is the 68 percent of families in total have succeeded to cross poverty line (Yunus et al., 2010). Today, the Grameen Bank is an inspiring social enterprise for the many of countries. So that, governments and institutions implement similar micro-lending solutions for their citizens. As a founder, Muhammad Yunus has become a global scholar who visits countries and shares his experiences with the social entrepreneurs, academicians, faculty students and people who are interested in.

\subsection{Case of Ashoka Foundation (USA)}

Another respectable name in the social entrepreneurship field is certainly William Bill Drayton who is the founder of Ashoka foundation. He is a pioneer for many of the current social entrepreneurs. He studied at Harvard University and worked for U.S. Environmental Protection Agency (EPA) from 1977 to the time when he founded
Ashoka Foundation in 1980. As a social enterprise, Ashoka supports individuals and their entrepreneurial activities. Also, a fellowship exists which is provided by Ashoka to individuals with social vision. By this, social entrepreneurs are supported and their ideas are improved (Brock \& Ashoka, 2008). Today, Ashoka as a social enterprise, is a rich source for distinct social entrepreneurs who follow the guidance of it from all over the world. It presents opportunities to leading individuals by providing networks and various supports. As a global result, 1,472 fellows in 48 different countries have exploited out of Ashoka's valuable services (Grenier, 2006). Academically, Ashoka is acknowledged as a leading figure of social entrepreneurship model and social entrepreneurs who have creative and applicable ideas for social change benefit from it.

\subsection{Case of ApproTEC (Kenya)}

ApproTEC provides technologies to farmers and small-scale entrepreneurs in East Africa. Its main goals are to promote technological tools for African farmers, improve the agricultural income and heal the subsistence of farmers (Brock \& Ashoka, 2008). Martin Fisher and Nick Moon are the founders of ApproTEC Kenya. The organization was established in 1991 but in 2005, it restructured and named as KickStart. KickStart basically promotes simple money-making tools to the poor entrepreneurs. It helps those entrepreneurs to conduct their own enterprises affectively. In Africa, it has provided technological tools to 150.000 businesses over the past 23 years. Today, each month, more than 800 new businesses are applying in order to exploit from KickStart's equipments (About Kickstart, 2013). These datas define KickStart as a successful social entrepreneurship example which innovatively approached to the African market and created a difference. However, their technological tools which have been increasingly demanded by African farmers have created its social entrepreneurial achievement. Concluding, KickStart evidently continues to expand in African market. Neighboring countries such as Mali, Tanzania, Uganda, Malawi, Rwanda and many others have explored the efficiency of KickStart. Therefore, Kickstart programs have grown and flourished in surrounding countries as well. It has been proved that 
the model of KickStart is replicable which is defined as one of the most essential features of social entrepreneurship model.

\section{Social Entrepreneurship at the Universities}

"Just a decade ago, there were virtually no business school courses or projects on social entrepreneurship. Today, most of top business schools have both".

Prof. Laura D'Andrea Tyson (Tyson, 2004, p. 1)

The outcomes of social entrepreneurial activities and ventures have been realized by the social sector for about twenty years. Academic interest to social entrepreneurship has also increased (Mair, 2008). Academic researches and books have been published that emphasize on this new model. However, It is a fact that students look at their career more in terms of personal values rather than making a contribution to society (Seelos \& Mair, 2005). In this respect, universities and institutions are the key factors for comprehending importance of social entrepreneurship. Furthermore, universities and business schools which consider the social entrepreneurship will also benefit from encouraging their students and stakeholders to become involved in social entrepreneurial activities (Mair et al., 2006). After existing developments and future aspect of social entrepreneurship began to spark academic interest (Santos, 2009), students started to pay attention to social entrepreneurship model as the result of occurred attention. Therefore, many universities and faculties are giving places to social entrepreneurship programs today. Table 2 is the attempt to illustrate the current examples of global social entrepreneurship programs at the different universities.

\section{Conclusion}

Social entrepreneurship is a phenomenon that is inquired by academicians and institutions to explore functionality of it.

Table 2. International Social Entrepreneurship Programs

\begin{tabular}{|l|l|l|l|}
\hline \multicolumn{1}{|c|}{ Country } & \multicolumn{1}{|c|}{ University } & \multicolumn{1}{c|}{ Program } & \multicolumn{1}{c|}{ Website } \\
\hline Columbia & $\begin{array}{l}\text { Universidad de los } \\
\text { Andes }\end{array}$ & $\begin{array}{l}\text { Program on Social } \\
\text { Initiatives }\end{array}$ & $\begin{array}{l}\text { http://administracionf. } \\
\text { uniandes.edu.co/ieso }\end{array}$ \\
\hline Denmark & Roskilde University & $\begin{array}{l}\text { The Centre for Social } \\
\text { Entrepreneurship }\end{array}$ & $\begin{array}{l}\text { www.socialt-entrepreneurskab. } \\
\text { dk }\end{array}$ \\
\hline France & INSEAD & $\begin{array}{l}\text { Social Entrepreneurship } \\
\text { Initiative }\end{array}$ & www.insead.edu/se \\
\hline India & $\begin{array}{l}\text { Tata Institute for Social } \\
\text { Sciences }\end{array}$ & $\begin{array}{l}\text { Masters in Social } \\
\text { Entrepreneurship }\end{array}$ & www.tiss.edu \\
\hline Italy & University of Bologna & $\begin{array}{l}\text { Master in Social } \\
\text { Entrepreneurship and } \\
\text { Philanthropy }\end{array}$ & www.misp.it \\
\hline Ireland & $\begin{array}{l}\text { University College } \\
\text { Cork }\end{array}$ & $\begin{array}{l}\text { MBS in Co-operative } \\
\text { and Social Enterprise }\end{array}$ & www.ucc.ie/en/ccs/ \\
CentreProgrammes
\end{tabular}

Source: Adopted from Brock and Ashoka (2008). 
It is a budding area that requires effort to illuminate its blurry context. Despite of the its explicit expansion on the global scale, its undefined scope poses more difficulties for future studies. Especially unclear boundaries, definition ground, lack of legitimacy, conceptual distinctiveness are only a few of the issues that may be encountered by the further researchers during their investigations. Hence, this paper is an academic attempt to contribute for comprehension of social entrepreneurship as a process and socio-economic model. It is obvious that augmenting similar studies will enable to develop social entrepreneurship and be significant for further advancement of social entrepreneurship.

\section{References}

About Kickstart. (2013). Retrieved September 30 Retrieved from: http://www.kickstart.org/about-us/.

Austin, J., Stevenson, H., \& Wei-Skillern, J., (2006). Social and commercial entrepreneurship: Same, different, or both ? Entrepreneurship: Theory and Practice, 30(1): forthcoming.

Bornstein, D. (2004). How to change the world: Social entrepreneurs and the power of new ideas. Oxford: Oxford Univeresity Press.

Bornstein, D. (2005). So you want to change the world? The emergence of social entrepreneurship and the rise of the citizen sector. Toronto: The Hart House Lectures.

Boschee, J. (1998). Merging mission and money: A board member's guide to social entrepreneurship. Retrieved from: http://www.socialent.org/pdfs/MergingMission.pdf.

Brock, D.D. \& Ashoka's Global Academy of Socia Entrepreneurship (2008). Social entrepreneurship: Teaching resources handbook for faculty engaged in teaching and research in social entrepreneurship. Retrieved from: http://papers.ssrn.com/sol3/papers. cfm?abstract_id $=1344412$.

Carter, J. (2009). The hope of our future world. Skoll World Forum, innovations, Social entrepreneurship: Shifting power dynamics, Special edition for the Skoll World Forum, 11-18.

Center for Advancement of Social Entrepreneurship. (2008). Retrieved September 20, 2013 from: http://www.caseatduke.org/documents/CASE Field-Building_Report_June08.pdf.

Certo, S. \& Miller, T. (2008). Social entrepreneurship: Key issues and concepts. Business Horizons, $51,267-271$.

Cho, A.H. (2006). Politics, values and social entrepreneurship: A critical appraisal. In: J. Mair J. Robinson \& K. Hockerts (eds.), Social Entre- preneurship (pp. 34-56). New York: Palgrave Macmillan.

Datta, D.M. (1961). The philosophy of Mahatma Gandhi. Wisconsin: The University of Wisconsin Press.

Davidsson, P. (2008). Some conclusions about entrepreneurship and its support. Evlan: World Entrepreneurship Forum. Retrieved from: http:// eprints.qut.edu.au/19042/1/c19042.pdf.

Davis, S. (2002). Social entrepreneurship: Towards an entrepreneurial culture for social and economic development. Youth Employment Summit. Retrieved from https://www.ashoka.org/files/yespaper.pdf.

Dees, J.G. (1998). The meaning of social entrepreneurship. Kauffman Center for Entrepreneurial Leadership.

Dees, J., Emerson, J. \& Economy, P. (2001). Enterprising nonprofits a toolkit for social entrepreneurs. New York: John Wiley and Sons, Inc.

Drucker, P.F. (1985). The practice of innovation, innovation and entrepreneurship practice and principles, Harper \& Row, New York.

Fowler, A. (2000). NGDOs as a moment in history: Beyond aid to social entrepreneurship or civic innovation? Third World Quarterly, 21(4), 637-650.

Friedman, M. (1970). The social responsibility of business is to increase its profits. New York Times Magazine.

Grenier, P. (2006). Social entrepreneurship: Agency in a globalizing world. In: A. Nicholls (ed.), Social Entrepreneurship: New models of sustainable social change (pp. 119-143). New York: Oxford University Press.

He, Q. (2008). No. In does the free market corrode moral character (pp. 8-9). The John Templeton Foundation. Retrieved from: http://www.templeton. org/market/.

Hoogendoorn, B., Pennings, E. \& Thurik, R. (2010) International review of entrepreneurship, 8(2), 1-42.

Leadbeater, C. (1997). The Rise of the social entrepreneur. Demos.

Light, P.C. (2008). The Search for social entrepreneurship. Washington, D.C.: Brookings.

Mair J., Robinson J. \& Hockerts K. (2006). Introduction. In: M. Johanna, J. Robinson \& K. Hockerts (eds.), Social Entrepreneurship (pp. 1-13). New York: Palgrave Macmillan.

Mair, J. (2008). Social entrepreneurship: taking stock and looking ahead. World Entrepreneruship Forum.

Mair, J. \& Noboa, E. (2006). Social entrepreneurship: How intentions to create a social venture are formed. In: J. Mair, J. Robinson \& K. Hockerts (eds.), Social Entrepreneurship (pp. 121-135). New York: Palgrave Macmillan. 
Marti, I. (2006). Introduction to part I - Setting a research agenda for an emerging field. In: J. Mair, J. Robinson \& K. Hockerts (eds.), Social Entrepreneurship (pp. 17-21). New York: Palgrave Macmillan.

Martin, R.L. \& Osberg, S. (2007). Social entrepreneurship: The case for definition. Stanford Social Innovation Review, 34-35.

Mort, G., Weerawardena, J. \& Carnegie, K. (2002) Social entrepreneurship: Towards conceptualization. International Journal of Nonprofit and Volun tary Sector Marketing, 8(1), 76-88.

Murray, R., Grice, C.J. \& Mulgan, G. (2010). The open book of social innovation. The Young Foundation, NESTA. Retrieved from: http://youngfoundation.org/wp-content/uploads/2012/10/The-Open-Book-of-Social-Innovationg.pdf

Nicholls, A. (2006). Introduction. In: A. Nicholls (ed.), Social entrepreneurship new models of sustainable social change (pp. 1-35). New York: Oxford University Press.

Peredo A.M. \& McLean, M. (2006). Social entrepreneurship: A criticial review of the concept. The Journal of World Business, 41(1), 56-65.

Perrini, F. \& Vurro, C. (2006). Social Entrepreneurship: Innovation and social change across theory and practice. In: J. Mair, J. Robinson \& K. Hoc kerts (eds.), Social Entrepreneurship (pp. 57-85) New York: Palgrave Macmillan.

Reis, T. (1999). Unleashing the new resources and entrepreneurship for the common good: A scan, synthesis and scenario for action. Michigan: W.K. Kellogg Foundation.

Robinson, J. (2006). Navigating social and institutional barriers to markets: How social entre- preneurs identify and evaluate opportunities. In J. Mair, J. Robinson \& K. Hockerts (eds.), Social Entrepreneurship (pp. 95-120). New York: Palgrave Macmillan.

Santos, F.M. (2009). A positive theory of socia entrepreneurship. INSEAD Working Paper, 2009/23/ EFE/ISIC. Available from: http://www.insead.edu/ facultyresearch/research/doc.cfm?did $=41727$.

Seelos, C. \& Mair, J. (2005). Social entrepreneurship: Creating new business models to serve the poor. Business Horizons, 48, 241-246. Doi: 10.1016/j.bushor.2004.11.006.

Seldin, T. \& Epstein, P. (2003). An educatoion for life. The Montessori Way, 1st edition.

Shane, S., Locke, E. \& Collin, C.J. (2003). Entrepreneurial motivation. Human Resource Management Review , 13, 257-279.

Skoll, J. (2006). Preface. In: A. Nicholls (ed.) Social entrepreneurship: New models of sustainable social change (pp. 5-6). New York: Oxford University Press.

Thake, S. \& Zadek, S. (1997). Practical people, noble causes. How to support community based social entrepreneurs. New Economics Foundation.

Tyson, L.D. (2004). The Economic Times. Retrieved from: http://articles.economictimes.indiatimes.com/2004-05-02/news/27386154_1_socialentrepreneurs-social-enterprises-social-services.

Yunus, M. (2007). Creating a world without poverty: Social business and future of capitalism. New York: Public Affairs.

Yunus, M., Moingeon, B. \& Ortega, L.L. (2010) Building Social Business Models: Lessons from the Grameen Experience. Long Range Planning, 308-325. Doi: 10.1016/j.lrp.2009.12.005. 